\title{
Interview with Dean Michael Strong
}

\author{
Visionary, driver, and leader in excellence
}

Sissi Cao (Meds 2016) and Joyce Zhang (Meds 2015)

Faculty Reviewer: Dr. Michael J Strong, MD, FRCPC, FAAN, FCAHS

As students sitting in the Office of the Dean, we had every reason to be nervous because in a few minutes, we would have the distinct privilege of speaking with Dr Michael Strong. We had taken a break from our daily routine and stepped into Dean Strong's brightly lit office in the Rix Clinical Skills Building. Dr Strong was kind enough to sit down with us and share stories about his illustrious career, as well as delve into the future of medical education, the role of physicians and the Schulich School of Medicine \& Dentistry.

Dr Michael Strong was born in Windsor and raised in Leamington. He completed 2 years of undergraduate studies in biochemistry at Queen's University before entering medicine. His relationship with Western University began in 1982 when he began an internship in internal medicine and subsequently completed his training in neurology in 1987. From there, his career took an interesting turn when he joined the National Institutes of Health for 3 years doing post-graduate studies. During his time at Fort Detrick in Frederick, Maryland he developed the first-ever rabbit model for amyotrophic lateral sclerosis (ALS), also know as Lou Gehrig's disease, a degenerative disease of upper and lower motor neurons. Dr Strong rejoined Western in 1990 as a clinician-scientist and began his scientific, clinical and teaching career. He stayed on and eventually became chief/co-chair of neurology from 2000 to 2010 , then dean of Schulich School of Medicine \& Dentistry in 2010.

\section{UWOMJ: What was your path to becoming dean?}

Dr Michael Strong: You never start your life off saying you're going to become a dean. It just sort of happens. I started off my research career doing experimental neuropathology. The reason I went to the lab that I chose was because of the work they had been doing on Lou Gehrig's disease in Guam in the Western Pacific, where the incidence was 3000- to 4000-fold higher than what you would see anywhere else in the world. To this day, we developed the only animal model of reversible ALS. We developed the first technique that would allow me to isolate the motor neurons, grow them in culture and get them to survive. So I became an experimental neurobiologist. Ten years later, I was doing a lot of work in protein chemistry. We'd isolate the proteins and look at their modifications. Ten years after that, we now have found ALS to be an RNA-mediated disorder and are viewed as being the leaders. But if you had asked me 20 years ago if I'd be doing RNA biology - [laughs]. Just like I would have never believed I would become chief of neurology, co-chair of the department or the dean of the medical school. But these are just things that happen over your lifetime.

\section{What is your life like outside of being dean?}

I still have my lab - I'm there every Monday morning, Tuesdays for grand rounds in clinical neurological sciences and Thursdays for journal club. I have three graduate students that I meet with every week. And I do a half-day of clinic every Tuesday morning. Those pieces of my life continue on. As for hobbies, my wife and I love to garden. We love to camp and spend a lot of time camping with our kids. And then as we got older we started golfing. We love to ski and we do love to travel because there are so many neat places to go to in the world. So we try to lead a quasi-normal life.

\section{Where is medical education heading?}

There is a difference in what people are looking for in lifestyles now. The day of people like myself and some of my predecessors working 100 hours per week and trying to drive a lab forward are few and far between. I think one of the things we're going to have to be more cautious about is ensuring that people understand what balance really means. If you're going to be a physician you're going to have to look after yourself as much as anybody else. As we move forward, we're going to have to cautiously think about true balance: between being an individual, being a physician, having a family and our roles in society.

Second, the rate of change in science is phenomenal. Patients have the capacity to send off their blood and get their entire genome back in weeks. And then they come into your office and say, 'I've got a Bcl-1 mutation - what does that mean?' Physicians need to understand how to get into new literature to better answer those questions, but there also needs to be better systems in place in order for physicians and practices to become integrated with emerging science.

Third, we have decided at this school to do simulations. You already get tons of it: patient simulations, anatomy simulations - just name it we're doing it. But there's a difference between doing simulation because you need to be educated in that realm versus doing simulation because you want to be leading in their development. I'm never interested in doing something just because you have to. If you're going to do it, do it well enough that you are actually creating new knowledge that goes along with that. My medical educators are thinking about what is next in the simulation curriculum and what resources are required if we're going to be a leader in it.

\section{What is changing for physicians in the future?}

Physicians are the ones that everyone trusts. We get to see the impact of a lot of things that are happening in society, so I think we have a role and responsibility. At this school, I see everything that students do in terms of social responsibility, which is something I'm 


\section{PROFILES}

really proud of. It's got nothing to do with me, nothing to do with Carol Herbert, the previous dean, or anybody before us. It seems to be intrinsic to the students. You folks have said 'this is our responsibility' - don't lose it.

\section{What do you think are the future roles of Schulich?}

There are several roles for Schulich locally, nationally and internationally. Locally, the school must take responsibility in order to best serve a population as diverse as that of Southwestern Ontario. As a tertiary care center, we serve a population of 6.2 million that has everything from absolute rural and underserviced populations and First Nations right through to urban populations. Everyone has different health care requirements. So why is health policy established somewhere else? It shouldn't be. I think the school has to take a major lead role in being the determinant of health in this region. The Interfaculty Program in Public Health will be up and running starting in September. It took 18 months from inception; that's how quickly we're moving and building. It will be the only case-based Masters of Public Health program in North America, so we'll be cutting new pathways there. We're focusing on leadership and social responsibility and teaching using cases with an international flavour.

Nationally, there 17 medical schools in Canada and I want to have our school clearly identified and recognized as a leader in health implementation and social responsibility. On the international level, no school can exist in isolation anymore. There is so much for us to learn from other areas of the world. It doesn't matter if we're talking about Africa, China, Saudi Arabia, Budapest or Detroit. These are areas we're developing very strong linkages with: student exchanges, professor exchanges and curriculum development. Over the rest of my term I see our school really developing in a meaningful way those types of bidirectional relationships. There's a great amount happening at this school that most people don't see. I'm really changing the focus and direction of this school.

\section{Do you have one take-home message for those reading this ar- ticle?}

It's a great school. There is so much to be proud of. From the students through to faculty, the achievements of this school are astounding. It's hard to see when you're in the middle, but when you're standing outside of it and you get a chance to look, you know. I travel the world doing things for this school and people are getting to know us. They know our curriculum and what we do in terms of research. So for students, you can be proud. There are many things that are happening here that have got nothing to do with me. This is just the history and the nature of our school.

Introspection and vision are the characteristics that make Dean Strong a great leader, evident through the plans he has already set in motion but also in the passion he brings to his position. His dedication to excellence also permeates through his clinical, scientific and academic careers. There is no doubt the work Dr Strong is championing will drive the Schulich School of Medicine \& Dentistry forward as a national and international leader in medical education, patient care and research. 